Article

\title{
Safe Harbor Policies for Juvenile Victims of Sex Trafficking: A Myopic View of Improvements in Practice
}

\author{
Kimberly Mehlman-Orozco \\ The Justitia Institute, P.O. Box 30654, Alexandria, VA 22310, USA; E-Mail: the.justitia.institute@gmail.com; \\ Tel.: +1-703-362-9405
}

Submitted: 26 April 2014 | In Revised Form: 18 September 2014 | Accepted: 29 September 2014 |

Published: 23 February 2015

\begin{abstract}
Current social and political realties have focused attention on human trafficking in the United States. Although new mechanisms for criminalizing offenders and protecting victims are increasingly funded and implemented across the country, empirical exploration into the efficacy of these interventions is lacking. This article uses yearly count data on juvenile prostitution arrests aggregated at the state level to explore the criminalization of commercial sexually exploited children post safe harbor policy implementation. Preliminary data from four states suggests that the passage of safe harbor laws may not reduce the number of juveniles arrested for prostitution crimes. Implications for future research are discussed.
\end{abstract}

\section{Keywords}

commercial sexual exploitation of children; CSEC; human trafficking; prostitution; safe harbor; sex trafficking; Trafficking Victims Protection Act; TVPA

\section{Issue}

This article is part of the special issue "Perspectives on Human Trafficking and Modern Forms of Slavery", edited by Siddharth Kara (Harvard Kennedy School of Government, USA).

(C) 2015 by the author; licensee Cogitatio (Lisbon, Portugal). This article is licensed under a Creative Commons Attribution 4.0 International License (CC BY).

\section{Introduction}

Following the passage of the Trafficking Victims Protection Act of 2000, lobbyists, practitioners, academics, legislators, and law enforcement agencies have all clamored to evaluate and address the issue of human trafficking in the United States. Human trafficking is defined as the recruitment, transportation, harboring or receipt of persons through the use of force, fraud, or coercion for the purpose of exploitation (United Nations, 2000). In the United States, this crime often involves the commercial sexual exploitation of women and minors. Sex trafficking is considered a severe form of trafficking and is defined as "the recruitment, harboring, transportation, provision, or obtaining of a person for the purposes of a commercial sex act" (Victims of Trafficking and Violence Protection Act of 2000, p. 1470). According to the National Center for Missing and Exploited Children (NCMEC) (n.d.), commercial sexual exploitation of children (CSEC) "occurs when individuals buy, trade, or sell sexual acts with a child." With estimates of 100,000 juvenile sex trafficking victims nationally (Office of Juvenile Justice and Delinquency Prevention [OJJDP], 2013), bipartisan social and political resources mobilized quickly to combat this heinous crime. Although the United States has lagged behind its European counterparts in its response to modern slavery (Wooditch, DuPont-Morales, \& Hummer, 2009), with most interventions being implemented post-2000; legislators are making up for lost time with a flood of policy and funding in recent years. For example, in an attempt to curtail the crime of human trafficking locally, states have passed laws ranging from increased sentences for human traffickers and training for law enforcement to protective policies for victims and related services. However, despite 
widespread speculation on behalf of human trafficking lobbyists and legislators, empirical research is infrequently used to evaluate the efficacy of these interventions (Van der Laan, Smit, Busschers, \& Aarten, 2011; Wooditch, 2011b).

In an attempt to better inform the human trafficking discourse, the current study provides an exploratory investigation into the criminalization of commercial sexually exploited children post-safe harbor policy implementation. Safe harbor policies "recognize prostituted minors as victims instead of delinquents", and are designed to provide commercial sexually exploited children with protection and services, instead of prosecution and detention (Geist, 2012, p. 71). Practitioners market safe harbor policies as serving four functions:

(1) Decriminalizing prostitution for anyone under a specific age;

(2) Diverting victim minors from delinquency proceedings toward supportive services;

(3) Providing specialized services for minor victims;

(4) Reclassifying prostituted minors as victims or sexually exploited children (American Bar Association [ABA], 2013).

The state of New York adopted the first safe harbor law in 2008 and since then 18 states have followed suit by legislating their own variation. One state, Texas, judicially produced the policy change with a state Supreme Court case, In the Matter of B.W. (2010). The case involved a thirteen-year-old juvenile who was arrested and prosecuted for soliciting an undercover police officer for oral sex in exchange for \$20. The Supreme Court of Texas later overturned the conviction, citing that the juvenile was a child victim of adult sexual exploitation and not a juvenile offender.

Despite a growing body of legislation and legal precedent for protecting juvenile victims of commercial sexual exploitation, it is unclear whether safe harbor policies reduce the number of prostituted juveniles being criminalized. While protection for commercial sexually exploited youth may be the letter of the law internationally (United Nations, 2000), federally (Victims of Trafficking and Violence Protection Act of 2000, 2000), and now in states with safe harbor statutes, legislative change is not necessarily akin to implementation change. Instead of treating juvenile sex trafficking survivors as victims, responding law enforcement agents are often inclined to arrest, detain, and hold human trafficking victims as a result of misidentification or to compel protection, cooperation, or service provision (Adelson, 2008; Drasin, 2012; Kittling, 2006; Office of Victims of Crime Training and Technical Assistance Center [OVCTTAC], n.d.; Reid \& Jones, 2011; Wharton, 2010). This disconnection between policy and practice has highlighted a critical need for a more victim-centered approach in responding to human trafficking incidents, especially for child victims of sex trafficking. In 2011, the Office of Juvenile Justice and Delinquency Prevention (2014) convened the National Research Council (NRC) and the Institute of Medicine (IOM) to create an interdisciplinary Committee on Commercial Sexual Exploitation and Sex Trafficking of Minors in the United States. This committee identified three principles to guide the processing of commercial sexually exploited children in the United States:

(1) Commercial sexual exploitation and sex trafficking of minors should be understood as acts of abuse and violence against children and adolescents;

(2) Minors who are commercially exploited or trafficked for sexual purposes should not be considered criminals;

(3) Identification of victims and survivors and any intervention, above all, should do no further harm to any child or adolescent (OJJDP, 2014, p. 5).

Criminalization often further hampers the already damaged rapport between minor human trafficking victims and law enforcement (OVCTTAC, n.d.). It is important to better understand whether safe harbor laws are achieving their intended function by reducing the criminalization of juvenile sex trafficking survivors.

This paper begins by discussing anti-trafficking policy in the United States. This information is used to explain why juvenile victims need additional protections, and how safe harbor laws claim to provide these safeguards. While advancements in policy are considered victories in the advocacy community, I use organizational change theory to explain why these legislative advancements may not necessarily manifest into changes in practice. $A$ discussion of organizational change concepts, such as coercive isomorphism and ceremonial change, is used to establish the need for the current empirical inquiry. Data, sampling, and analytic methods are discussed before exploring juvenile prostitution arrests, pre- and post-safe harbor implementation in four states. Although exploratory in nature, the results are used to establish the need for additional human trafficking intervention evaluation research.

\section{Background}

\subsection{Commercial Sexual Exploitation of Minors}

The Trafficking Victims Protection Act (TVPA) of 2000 served as a catalyst to anti-trafficking policies and practices in the United States (Victims of Trafficking and Violence Protection Act of 2000, 2000). The act, initially passed in 2000 and reauthorized in 2003, 2006, 2008, and 2013 , defined human trafficking for the country, and set up formidable action items to combat it (U.S. 
Department of State, n.d.). Section 106 of the act recognizes the need for more prevention efforts directed toward high-risk victim populations. Section 107 highlights a need for additional protections and services for victims, while sections 111 and 112 call for increased prosecution of offenders. However, despite increases in resources, knowledge, and political pressure, certain policy recommendations outlined in the TVPA failed to materialize in practice for some jurisdictions. For example, although the TVPA defines commercial sexually exploited children as victims of human trafficking, most jurisdictions continue to criminalize prostituted juveniles similarly to prostituted adults (Adelson, 2008).

According to Section 103, 8A of the Trafficking Victims Protection Act (TVPA) of 2000, children do not need to be forced, defrauded, nor coerced to be considered victims of sex trafficking. The definition of child sex trafficking implies that juveniles do not have the legal capacity to consent to exploitation and that illicit means are implicit when a juvenile is induced to commit a commercial sex act. Although juvenile status is defined by Section 103, 8A of the TVPA (2000) as anyone under the age of 18 , the exploitation of minors under the age of 14 carries harsher punishment. Section 1591, b of the TVPA (2000) states that sex traffickers are subject to fines and life imprisonment if convicted of trafficking a minor under the age of 14 , whereas sex trafficking of children between the ages of 14 and 17 only carries a maximum of 20 years in prison and/or fines. However, these punishments are infrequently imposed. Although there are an estimated 100,000 juvenile sex trafficking victims in the United States according to the Bureau of Justice Statistics, there were less than 150 juvenile sex trafficking cases prosecuted in 2011, with only 81 convictions in that same year (U.S. Department of Justice, 2013). To put this information into perspective, while other forms of crime have clearance rates that range from $11.9 \%$ for motor vehicle theft to $62.5 \%$ for murder (FBI, 2013), limited data on juvenile sex trafficking prevalence and prosecution suggests that less than $0.01 \%$ of estimated cases are identified and successfully prosecuted.

As victims of a severe form of human trafficking, commercial sexually exploited children are afforded numerous protections under Section 107, c1 of the TVPA (2000), namely sex trafficked juveniles shall:

(1) Not be detained in facilities inappropriate to their status as crime victims;

(2) Receive necessary medical care and other assistance;

(3) Be provided protection if a victim's safety is at risk or if there is danger of additional harm by recapture of the victim by a trafficker (p. 1477).

The letter and spirit of these provisions are to generally safeguard juvenile sex trafficking survivors. However, these protective directives can be difficult to effectuate in practice. Given the trauma bond that often accompanies human trafficking victimization, survivors may be initially unwilling to cooperate with law enforcement (National Center for Missing and Exploited Children [NCMEC], n.d.). In response, law enforcement agencies may utilize arrest, detention, and holding as measures to provide protection and coerce treatment for un-cooperating victims (OVCTTAC, n.d.). However, this may further exacerbate the already strained relationship between child survivors of sex trafficking and law enforcement; thus, leading to cyclical victim criminalization.

For example, in 2002 convicted human trafficker Carlos Curtis enticed a 12-year-old runaway girl to leave New York City and come with him to Washington D.C., where he took sexually explicit photographs of her, raped her, and forced her to prostitute herself on the streets (U.S. v. Curtis, 2006). Although the victim was eventually identified by law enforcement as a sex trafficking survivor, she was not protected from various forms of criminalization. Since the minor victim (A.P.) did not have any family who could retrieve her from D.C. and there was no social service worker to care for her, she was transferred to Oak Hill, a juvenile detention facility, where two inmates raped her with a toothpaste tube (U.S. v. Curtis, 2006). A.P. later returned to living and working on the streets in New York and began prostituting to support herself, where she was arrested and re-incarcerated. Given A.P.'s family situation and trauma, the prosecution justified holding A.P. in a detention facility as a material witness pending the trial of Carlos Curtis. Despite being afforded counseling and therapy, A.P. never availed herself to services and returned to the commercial sex industry post-trial (U.S. v. Curtis, 2006).

Unfortunately, despite their victim status, juvenile survivors of sex trafficking continue to be arrested and detained for crimes related to their victimization, namely involvement in the commercial sex industry. The Uniform Crime Report collects data on the total number of persons arrested, cited, or summoned for criminal acts. Demographic data, along with the most serious charge filed, are reported for each arrested person. According to aggregate level UCR data, between 1,000-1,800 juveniles are arrested for prostitution offenses yearly. Ultimately, a growing body of research identifies a gap between protections for juvenile victims of sex trafficking in law and in practice (Adelson, 2008; Drasin, 2012; Green, 2008; Kittling, 2006; Reid \& Jones, 2011; Wharton, 2010).

It is important for commercial sexually exploited children (CSEC) to be protected from criminalization because these minors often suffer from multiple layers of trauma that are not easily recognizable (Geist, 2012). The emotional, physical, psychological abuse, and torture 
CSEC experience often precedes their human trafficking victimization. Before becoming victims of human trafficking, these juveniles are considered high-risk on a number of fronts. For example, these prostituted kids typically grow up in dysfunctional environments, being "in-and-out of various parts of the social services system including private NGOs, foster homes, and runaway shelters" (Geist, 2012, pp. 74-75). Yet, despite having high risks and experiencing multiple forms of traumatic victimization, these juveniles often fail to receive directed services and are typically forced into a "revolving door of exploitation and arrest" (Geist, 2012, p. 74).

In a movement toward a more victim-centered approach to human trafficking response, anti-trafficking organizations like Polaris Project (2013) and Shared Hope International (2009) began publicly highlighting the gap between federal law and practice, denouncing the criminalization of child sex trafficking survivors. As a result of lobbying efforts, states recently began passing safe harbor laws. Safe harbor laws further clarify the distinction between prostitute and human trafficking victim at the state level. Similar to federal law (Victims of Trafficking and Violence Protection Act, 2000), safe harbor policies generally define prostituted juveniles ${ }^{1}$ as severely trafficked persons in need of services (Drasin, 2012). However, it is unclear how these state-level policies manifest in practice and whether they have addressed the federal legal gap.

The spirit of the safe harbor policy can easily lead to the assumption that the number of juveniles arrested for the crime of prostitution would dissipate after the policies are implemented. However, this assumption is not yet empirically explored nor validated by evidence. Organizational change theory can be used to better understand the opportunities and barriers to effectuating these changes in practice.

\subsection{Theory}

Police organizations and courts must drastically change their methods of processing prostituted juveniles in order to fulfill the policy modifications outlined in state safe harbor laws and the federal Trafficking Victims Protection Act. Historically, the criminal justice system treated prostituted juveniles as criminals (Adelson, 2008; Drasin, 2012; Kittling, 2008; Reid \& Jones, 2011; Wharton, 2010); however, the aforementioned anti-trafficking policies recategorize commercial sexually exploited children as victims. Although CSEC decriminalization may seem simple in abstract, organizational and/or cultural barriers may inhibit this change in practice. According to Dimaggio and Powell (1983), there are three mechanisms of organizational change: (1) coercive isomorphism, which stems from political influence; (2) mimetic isomorphism, which develops from uncertainty; and (3) normative isomorphism, a byproduct of professionalization. Theoretically, safe harbor laws may be best categorized as resulting from coercive isomorphism or pressures to change from the environment (e.g. social and political) (see Dimaggio and Powell, 1983). However, given the coercive nature, these changes may be largely ceremonial, as opposed to true adjustments (Dimaggio \& Powell, 1983). For example, Wooditch (2011a) found that anti-trafficking laws passed at the national-level may be more symbolic, as legislators tend to be motivated by the general public's perception or reaction to the passage of the law rather than the actual implementation or substance (Wooditch, 2011a). Without any accountability, police may relegate to processing commercial sexually exploited juveniles as prostitutes, which may be institutionally accepted as a normative practice.

Asking police agencies to treat girls and boys engaged in the crime of prostitution as victims may be counter to established police perceptions and experiences. Given the nature of the crime, child survivors of sex trafficking often develop a strained relationship with law enforcement (NCMEC, n.d.; OVCTTAC, n.d.; Reid, 2010; Reid \& Jones, 2011). Human traffickers use psychological manipulation, violence, and drug dependency to create a trauma bond between the child victim and the offender (Clawson \& Grace, 2007; Hopper \& Hidalgo, 2006; NCMEC, n.d.; Reid \& Jones, 2011). Victims are taught not to trust law enforcement and are instead manipulated into developing an emotional connection with their trafficker, which serves as a psychological survival mechanism (Hopper \& Hidalgo, 2006; NCMEC, n.d.; Reid \& Jones, 2011). As a result, commercial sexually exploited youth infrequently cooperate with law enforcement and may not even perceive themselves as victims (NCMEC, n.d.; OVCTTAC, n.d.; Reid, 2010; Reid and Jones, 2011). Given their lack of cooperation and involvement in criminal activity (prostitution, drugs, etc.), police may perceive commercial sexually exploited youth as criminals, regardless of the shifting paradigm away from criminalization and toward protection (Adelson, 2008; Drasin, 2012; Kittling, 2008; OVCTTAC, n.d.; Wharton, 2010). It is important to recognize that employee cultural modes of thought take time to adapt to new environments because they are complex and more difficult to change than the structure of an organization or a policy (Smircich, 1983).

Police culture modes of thought are bound by rationality, time, and available information, among other organizational constraints (Gigerenzer \& Todd, 1999; Simon, 1956). In order to make sense of complex information, police use easily accessible knowledge,

${ }^{1}$ Qualifying juvenile age cut-off varies by state, ranging from 13 to 17. 
heuristics, and structures to help make decisions (see Gigerenzer \& Todd, 1999). While these methods of data processing facilitate quick assessments, limited accessible knowledge, problematic heuristics, and constrained organizational structures can lead to stereotypes (standardized and simplified concepts) or tunnel vision (filtering evidence through a prefabricated outcome lens), which can result in problematic policing (see Findley \& Scott, 2006). Since bounded rationality affects police cultural modes of thought, it may be difficult for officers to perceive and treat commercial sexually exploited juveniles as victims if and when they do not behave like a stereotypical victim. Unlike other types of victims, CSEC often fail to cooperate with law enforcement, exhibit an emotional bond with their purported victimizer, and engage in what is perceived as consenting criminal activity. Stereotypically, these victims may behave more like offenders and/or co-conspirators, which could partially explain continued criminalization.

Ultimately, police organizations that do not comply with the Trafficking Victims Protection Act are not yet held accountable for deviation from proscribed practice. More importantly, failing to protect commercial sexually exploited youth from criminalization at the arrest level may not affect overall organizational legitimacy, and as such this deviation may be of little consequence to police organizational leaders. Without any organizational accountability and competing normative perceptions, it is unclear whether safe harbor laws have decreased the criminalization of commercial sexually exploited youth. The present study explores the effects of safe harbor policy change through descriptive data on juvenile prostitution arrests before and after safe harbor implementation.

\section{Present Study}

Using FBI Uniform Crime Report data, this study explores the rate of commercial sexually exploited juveniles arrested for the crime of prostitution pre and post-safe harbor implementation. While exploratory in nature, this analysis is unique in that prior research on the empirical effects of safe harbor laws is lacking in the United States, and there is little data to empirically evaluate the human trafficking phenomenon, much less anti-trafficking interventions (see Van der Laan et al., 2011). Establishing an evidence-base is imperative to improving the efficacy of anti-trafficking policy and practice. Since safe harbor policies are typically passed by state legislature, the unit of analysis for this study is the state level.

\footnotetext{
${ }^{2}$ As soon as imputations were completed, NCJRS provided the data to the author. However, at time of submission the data
}

\subsection{Data}

Data on the key variable of interest, juvenile arrests for prostitution, were obtained from the FBI's Uniform Crime Report. The FBI Uniform Crime Report synthesizes data collected from the National Incident Based Reporting System (NIBRS). NIBRS collects detailed information from police agencies on every crime occurrence recorded by police, including demographic characteristics of victims and offenders, crime location and type. FBI Uniform Crime Report data files were obtained through the Office of Juvenile Justice and Delinquency Prevention (OJJDP) Easy Access to FBI Arrest Statistics (EZAUCR) database, which includes imputations for missing data. In the imputation algorithm, data for any law enforcement agency reporting 3 to 11 months is increased by a weight of twelve and divided by the number of months reported (Puzzanchera \& Kang, 2013). For jurisdictions reporting 0 to 2 months, the counts are estimated using rates from jurisdictions with similar populations, which reported 12 months of data located within the same state (Puzzanchera \& Kang, 2013).

According to the OJJDP website, the EZAUCR provides access to juvenile arrest statistics (under the age of 18) at the national, state, and county level. The data also include information on adult arrests separately or with all ages combined. The data archive includes information from 1994-2010. Data for the year 2011 was obtained separately for this project and directly from NCJRS ${ }^{2}$. EZAUCR provides arrest statistics for 29 detailed offense categories including prostitution (Puzzanchera \& Kang, 2013). Data on adult arrests for prostitution were also obtained from the EZAUCR for comparison.

Data for the intervention variable (safe harbor laws) were collected from Polaris Project (2013). Polaris Project is an anti-trafficking lobbying organization and service provider, which catalogs and tracks human trafficking legislation. According to Polaris Project, as of 2013, 18 states passed safe harbor laws: Arkansas, Connecticut, Florida, Illinois, Kansas, Kentucky, Louisiana, Massachusetts, Michigan, Minnesota, Nebraska, New Jersey, New York, North Carolina, Ohio, Tennessee, Vermont, and Washington. The data collected from Polaris Project was corroborated by references to the original statutes.

\subsection{Sampling}

While 18 states passed safe harbor policies as of 2013, only five of these policies were passed prior to 2011, of

had not yet been uploaded to the OJJDP EZACR website. Years 2012 and 2013 have not yet been processed. 
which only four had original data available for both preand post-intervention years (see Table 1). Only states with safe harbor laws passed before 2011 were included in the final analysis, to allow for post-policy data comparison $^{3}$. The first safe harbor law was passed in 2008 by the state of New York. Four states passed safe harbor statutes in 2010: Connecticut, Illinois, Texas, and Washington. Statutes from Connecticut, Illinois, and Washington became immediately effective after being signed into law in 2010. The court decision from Texas also resulted in theoretically immediate policy by creating legal precedent. The safe harbor law from the state of New York, however, came into effect nearly two years after being signed into law in 2008, on April 1, 2010.

Annual arrest statistics for juveniles and adults were collected separately from the EZAUCR for years 1994 through 2011. Information was initially collected on all five of the states that passed safe harbor laws prior to $2011^{4}$. Data reported to the FBI were incomplete for several years and jurisdictions. Imputation procedures were performed by NCJRS to provide estimates for the missing data. States with coverage indicators less than $90 \%{ }^{5}$ were considered as having large amounts of imputed data by OJJDP; however, given the exploratory nature of this study, this alone did not preclude the state or the year in question from inclusion. The state of Illinois, however, was precluded from the analysis for having over 50\% imputed data. Between 1994 and 2011 over $77 \%$ of the data for Illinois was imputed: 1994 (82\%) 1995-2009 (77\%), and 2010-2011 (78\%). As such, the final sample includes four states with 18 observations per state, for a total of $n=72$ data points.

Included states had much less missing data. The highest proportions of imputations for Connecticut were: 1994-1995 (15\%), 1996 (16\%), 1997 (15\%), and 1998 (14\%). The highest proportions of imputations for New York were: 1999 (16\% imputed), 2000 (17\% imputed), and
2001 (16\% imputed). Texas provided over $90 \%$ of data for all years 1994-2011. The highest proportions of imputations for Washington state were: 1994 (21\%), 1995 (29\%), 1996-1997 (28\%), 1998 (26\%), 1999 (16\%), 2000 (26\%), 2001 (21\%), 2002 (16\%), 2003 (25\%), 2004 (14\%), 2005-2006 (13\%), 2007-2009 (21\%), and 2010 (20\%).

\subsection{Analysis}

Graphs of juvenile prostitution arrests are used to explore the criminalization of commercial sexually exploited children pre and post safe harbor policy implementation. The small sample size, few number of years post-safe harbor implementation, and generally small numbers of juvenile prostitution arrests per year preclude the use of more rigorous statistical testing at present. However, data on adult prostitution arrests are used as a comparison group within each state. Adding adults arrested for prostitution as a control group reduces the likelihood of Type I error. Type I error could occur if unexplained variance or noise affects the post safe harbor juvenile arrest rate, making it appear different from the pre safe harbor juvenile arrest rate, when it may not be a consequence of the safe harbor policy. Since adult prostitution arrests should not be affected by the safe harbor policy, but may be equally affected by unexplained variance or noise, this variable will create a non-equivalent comparison group. These data convey a first glance on the criminalization of commercial sexually exploited children pre-post safe harbor policy implementation, and provide a framework for developing more rigorous future evaluation. These descriptive statistics illustrate prima facie trends, which run counter to the letter and spirit of the policy. Juveniles continue to be arrested for the crime of prostitution after safe harbor policies are passed locally.

Table 1. Safe Harbor Laws by State.

\begin{tabular}{|c|c|c|c|}
\hline State & Statute & Year & Description \\
\hline Connecticut & $\begin{array}{l}\text { S.B. } 153, \text { Feb. } \\
\text { Sess. }\end{array}$ & 2010 & $\begin{array}{l}\text { Prohibits prosecution of prostituted juveniles aged } \leq 15 \text {; for ages } 16-17 \text { there is a } \\
\text { presumption of coercion. }\end{array}$ \\
\hline New York & $\begin{array}{l}\text { A.B. } 5258-C, 2007 \\
\text { Leg., 231st Sess. }\end{array}$ & $2008^{6}$ & $\begin{array}{l}\text { All prostituted juveniles aged }<18 \text { are deemed "sexually exploited children", and } \\
\text { presumed to meet the criteria for certification as a victim of a severe form of } \\
\text { trafficking as defined in section } 7105 \text { of title } 22 \text { of the United States Code, } \\
\text { Trafficking Victims Protection Act of } 2000 .\end{array}$ \\
\hline Texas & $\begin{array}{l}\text { Texas Supreme } \\
\text { Court, in the } \\
\text { matter of B.W. }\end{array}$ & 2010 & $\begin{array}{l}\text { Children under the age of } 14 \text { are legally incapable of consenting to sex. The case is } \\
\text { interpreted to prohibit charges for prostituted juveniles under the age of } 14 .\end{array}$ \\
\hline Washington & $\begin{array}{l}\text { S.B. } 6476,61 s t \\
\text { Leg., Reg. Sess. }\end{array}$ & 2010 & $\begin{array}{l}\text { "Sexually exploited child" is defined as any person }<18 \text { who is a victim of } \\
\text { commercial sex abuse. Presumption that prostituted juveniles meet the criteria for } \\
\text { certification as a victim of a severe form of trafficking as defined in section } 7105 \text { of } \\
\text { Title } 22 \text { of the United States Code. }\end{array}$ \\
\hline
\end{tabular}

\footnotetext{
${ }^{3} \mathrm{FBI}$ UCR data is available up to 2011 only at the time of analysis.

${ }^{4}$ One state was later removed for having over $50 \%$ imputed data-Illinois.
}

\footnotetext{
${ }^{5}$ Missing data for over $10 \%$ of jurisdictions within the state or more than $10 \%$ of months in a given year.

${ }^{6}$ Year passed/year effective was only different for the state of New York, 2008/2010 respectively.
} 


\section{Results}

Panel data are used to explore the rates of juvenile prostitution arrests post-safe harbor implementation. While exploratory in nature, these data suggest that juveniles continue to be criminalized through arrest post-safe harbor implementation. While some of the arrested juveniles may not be ultimately prosecuted for the crime of prostitution, the simple acts of being charged and detained may further traumatize these juvenile victims of sex trafficking, as evidenced in the literature and case law. Descriptive statistics illustrate negligible changes in the number of juveniles arrested for prostitution after safe harbor policies are passed, with small increases in Connecticut, New York, and Texas. Table 2 contains the descriptive statistics for the juvenile prostitution arrests per year, with post-safe harbor years highlighted.

Table 2. Juvenile prostitution arrests by State: 1994-AB2011.

\begin{tabular}{lllll}
\hline Year & Connecticut & New York & Washington & Texas \\
\hline 1994 & 21 & 91 & 74 & 94 \\
1995 & 7 & 92 & 46 & 104 \\
1996 & 8 & 110 & 42 & 74 \\
1997 & 9 & 128 & 27 & 96 \\
1998 & 9 & 152 & 24 & 102 \\
1999 & 2 & 207 & 24 & 110 \\
2000 & 5 & 210 & 22 & 115 \\
2001 & 5 & 227 & 35 & 92 \\
2002 & 15 & 115 & 40 & 88 \\
2003 & 2 & 45 & 61 & 103 \\
2004 & 4 & 35 & 36 & 120 \\
2005 & 1 & 56 & 42 & 92 \\
2006 & 3 & 128 & 49 & 120 \\
2007 & 1 & 25 & 64 & 126 \\
2008 & 4 & 61 & 66 & 139 \\
2009 & 0 & 25 & 70 & 124 \\
2010 & 1 & 14 & 39 & 92 \\
2011 & 2 & 136 & 24 & 108 \\
\hline
\end{tabular}

Data from the state of New York are presented separately from other implementing states in the time series charts because the safe harbor law for this state was enacted two years prior to implementation. As such, the gap between the signing of the statute (September 25,2008 ) and its implementation date (April 1, 2010) may provide a unique opportunity to illustrate changes post ratification versus post implementation.

New York's safe harbor law states that "the term 'sexually exploited child' refers to any person under the age of eighteen who has been subject to sexual exploitation because he or she...engages in any act as defined in section 230.00...of the penal law" (Scarborough,

\footnotetext{
${ }^{7}$ Policy announcement effects are illustrated with other media focused, yet ineffective, legislation such as 287(g). (see Koper, Guterbock, Woods, Taylor, \& Carter, 2013).
}

2008). Section 230 of the penal law includes all prostitution related offenses. Presumably, this implies that all prostituted juveniles under the age of 18 should be treated as victims instead of as offenders. However, this is not how the law is interpreted, which illustrates a disconnection between policy and practice. According to the Polaris Project (2013) the law only allows for the discretion to divert prostituted juveniles under the age of 16 into "Persons In Need of Services" (PINS) programs. Using data from the FBI Uniform Crime Report, trends outlined in Figure 1 suggest that the number of juveniles arrested for prostitution have not decreased post safe harbor law in the state of New York.

Juvenile prostitution arrests closely mirror that of adults in the state of New York (Figure 2). Although there was a small decrease in the number of juveniles arrested for prostitution after the bill was signed into law in 2008, there was also a reduction in the number of adults arrested for prostitution, which should be unaffected by the policy. More importantly, after the law actually became effective in 2010 , there was a large increase in the number of both juveniles and adults arrested for prostitution in 2011. The fact that there was a small reduction in the number of juveniles arrested for prostitution after the law was signed, but not when the law was implemented is interesting. Given the legislative, media, law enforcement, and public attention culminating around the signing of the bill, there may be an announcement effect ${ }^{7}$ as opposed to a true change. This could be an illustration of the potential ceremonial nature of these types of laws. Alternatively, it could be indicative of a lack of implementation training or support. These data suggest that the letter of the safe harbor law, which states that all prostituted juveniles are sexually exploited children, may not decrease the criminalization of sex trafficked children at the arrest level.

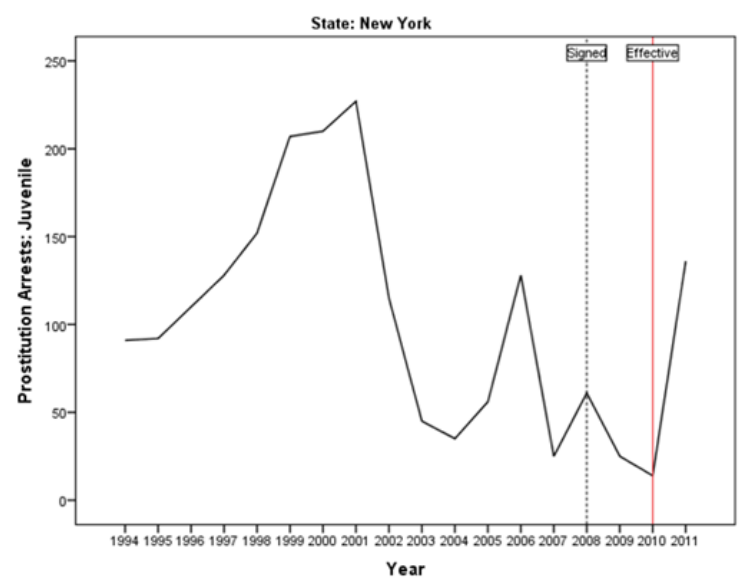

Figure 1. Juvenile prostitution arrests: New York. 


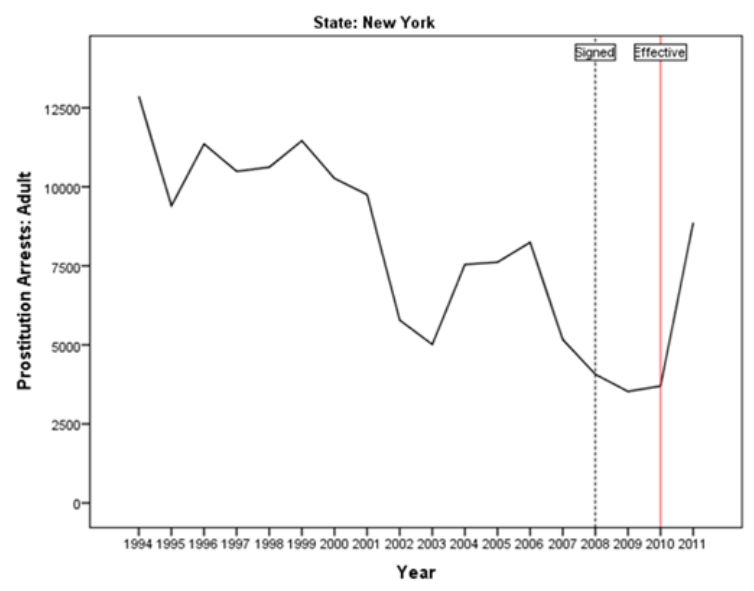

Figure 2. Adult prostitution arrests: New York.

Although there is less post-law data for comparison, findings from Connecticut, Texas, and Washington illustrate similar trends (Figure 3). The fluctuations in juvenile arrests for all three states often mirror trends in adult arrests for prostitution. Washington State evidenced a decrease in juvenile and adult prostitution arrests post safe harbor implementation. While the number of adults arrested for prostitution in Texas declined post Supreme Court decision, there was an increase in juvenile prostitution arrests. Connecticut also experienced a small increase in juvenile prostitution arrests post safe harbor implementation.

Across states and age groups, prostitution arrests appear to be declining in the United States. Although some may attempt to accredit these changes to advancements in policy, there has yet to be an empirical basis for that claim. In fact, these exploratory data suggest that safe harbor policies may not decrease the criminalization of juvenile sex trafficking survivors at the arrest level. The following section discusses the limitations of the present exploration and implications for future research.

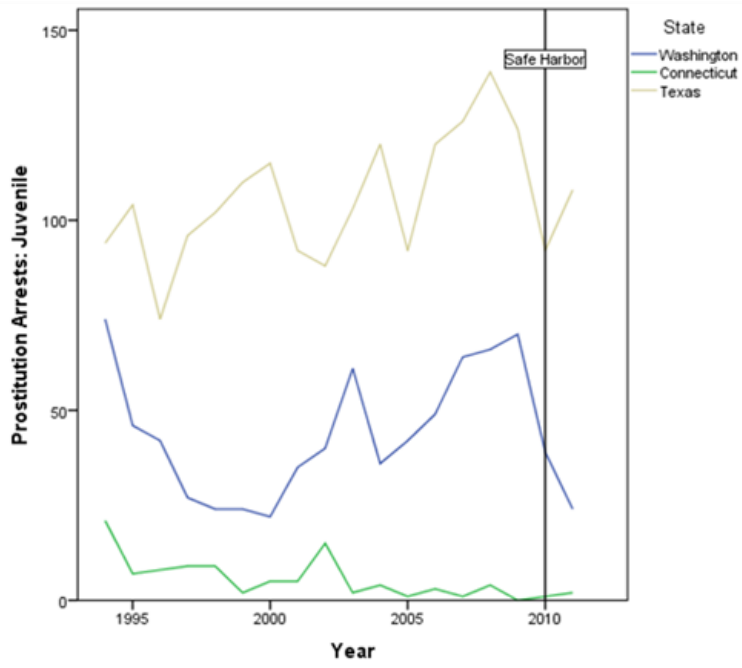

Figure 3. Juvenile prostitution arrests: Connecticut, Texas, and Washington.

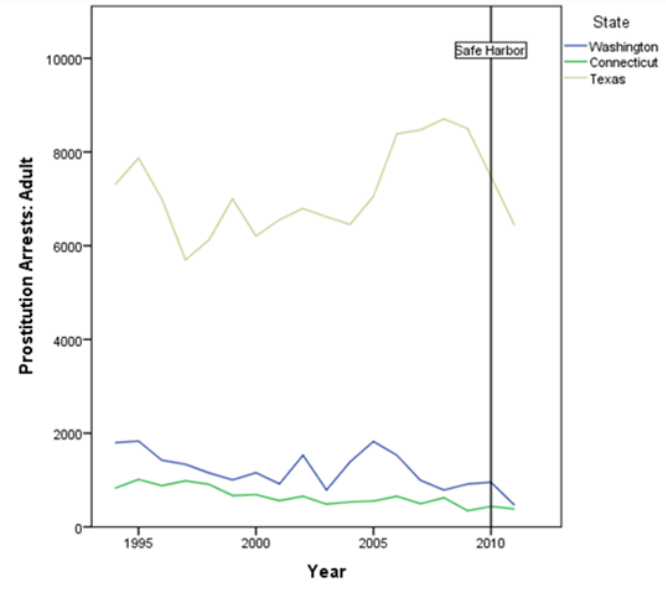

Figure 4. Adult prostitution arrests: Connecticut, Texas, and Washington.

\section{Discussion and Conclusions}

Recent legislative developments in the United States have further criminalized human traffickers and consumers, while increasing protections and service provision for victims. Yet, anti-trafficking lobbying organizations still continue to advocate for new policies, adding to the legislative arsenal at the disposal of practitioners and law enforcement. While some may focus on the need for new policies, it is equally as important to explore the utility of existing legislation. If practices are not fulfilling the spirit of the law by decriminalizing juvenile sex trafficking survivors, practitioners, legislators, and lobbyists need to understand why and adjust their efforts accordingly. While exploratory in nature, this study provides descriptive data to suggest that safe harbor policies may not be associated with a decrease in the number of juveniles arrested for the crime of prostitution. While these findings only apply to one form of criminalization, which may not be an important directive of all safe harbor policies, the criminalization of juvenile sex trafficking survivors through arrest should nevertheless be avoided, according to practitioner recommendations (NCMEC, n.d.; OJJDP, 2014; OVCTTAC, n.d.).

The results of the present study must be taken cautiously, however, given the extremely limited nature of the available data and analytic methods. A true evaluation of safe harbor policies should explore criminalization and decriminalization at each level of the justice process, including but not limited to: arrest, prosecution, conviction, and detention. While some safe harbor policies provide sweeping protections from all forms of criminalization for prostituted youth under the age of 18, such as Illinois' safe harbor law, others may only divert at the prosecutorial level, such as New York's safe harbor law. Ultimately, the present availability of data could only be utilized for an exploration into post-implementation arrest descriptive statistics. Given the small sample, lack of appropriate 
control measures, and simplified nature of the analytic strategy, no conclusions could be appropriately drawn from the presented results other than a discernable need for additional data and future research.

Although the present study was bounded by data restrictions, the availability of new data in the near future will facilitate and afford more rigorous research on the efficacy of safe harbor laws and barriers to CSEC protection. As of January 1, 2013, the FBI Uniform Crime Report began collecting data on human trafficking crimes reported to police (FBI, n.d.). Once the 2014 UCR data are released, there will be a total of 18 states that have implemented safe harbor statues with available post-intervention data for analysis. In concert, these additional data sources will provide the information needed for more rigorous policy evaluation. Future research should consider employing interrupted timeseries analysis to provide a more rigorous evaluation on the policy effects. Such analysis would need to overcome a number of potential shortcomings, including the pooling of policies that employ disparate age cut-off levels for whom is considered a de facto victim of sex trafficking. Analytic models should also attempt to control for other potential explanatory factors and variations in prostitution processing, including local level law enforcement efforts, such as raids or stings. Additional data could provide more complete information on the effectiveness of the safe harbor policy in decriminalizing juvenile victims of sex trafficking.

Prostituted juveniles are identified as victims in need of services by international, federal, and some state laws; as such, there is a general consensus among practitioners that these sex trafficking survivors should not be criminalized (ABA, 2013; NCMEC, n.d.; OVCTTAC, n.d.). Although some law enforcement and victim service providers may see fit to arrest commercial sexually exploited children as a mechanism for compulsory service provision, these juveniles often face multiple forms of complex trauma and a simple arrest can further their fear or negative perceptions of law enforcement (OVCTTAC, n.d.). Instead of being criminalized through arrests, detentions, or holding, the Federal Office for Victims of Crime Training and Technical Assistance Center (OVCTTAC) (n.d.) recommends for human trafficking task forces to immediately identify and refer the victims to appropriate local services and start building rapport, coupled with surveillance. Inclination to arrest is highlighted as a critical challenge to law enforcement; yet, OVCTTAC (n.d.) among other organizations explicitly state, "individuals under the age of 18 who are involved in commercial sex acts are to be considered victims of human trafficking" (n.p.).

Ultimately, it is important to understand that passing policy is only the first step to effectuating change in practice. True change requires reconciliation between the spirit, letter, and practice of anti-trafficking policies. Decriminalization at each level of the criminal justice process is imperative to achieving a victimcentered approach to human trafficking interventions. Assuming that safe harbor legislation decriminalizes prostituted juveniles de facto is a myopic view of the process. In order to be effective in protecting minor victims, it is essential to establish a stronger evidentiary basis for these anti-trafficking polices, as well as a method to monitor implementation. However, with that being said, the clandestine nature of the crime makes the acquisition of reliable data difficult, and true intervention evaluation near impossible (given the missing baseline data due to underreporting). To address these issues, legislators, practitioners, and lobbying organizations should work with researchers to establish mechanisms for reliable data collection and analysis.

\section{Acknowledgements}

The author would like to acknowledge her amazing children, Destiny, Mia, Rio, and Nico, as well as her loving husband Luis for their continuous support and inspiration. Additionally, the author would like to recognize and give thanks to Alese Wooditch and Laura Siller for providing helpful insight and edits on this manuscript and countless others.

\section{Conflict of Interests}

The author declares no conflict of interests.

\section{References}

Adelson, W. J. (2008). Child prostitute or victim of trafficking. University of St. Thomas Law Journal, 6, 96.

American Bar Association [ABA]. (2013). Safe Harbor Laws: Policy in the Best Interest of Victims of Human Trafficking. Commission on Homelessness and Poverty. American Bar Association Midyear Meeting. Retrieved from http://www.americanbar.org/ content/dam/aba/events/homelessness_poverty/2 013_Midyear_Meeting_Safe_Harbor_Laws/rich_ho oks_wayman_powerpoint.authcheckdam.pdf

Connecticut General Assembly. (2010). An Act Providing a Safe Harbor for Exploited Children. Public Act No. 10-115. Retrieved from http://www.cga.ct.gov/ 2010/ACT/PA/2010PA-00115-R00SB-00153-PA.htm

Clawson, H. J., \& Grace, L. G. (2007). Finding a Path to Recovery: Residential Facilities for Minor Victims of Domestic Sex Trafficking. Human Trafficking: Data and Documents. (Paper 10). Washington, D.C.: U.S. Department of Health and Human Services. Retrieved from http://digitalcommons.unl.edu/hum traffdata/10

DiMaggio, P. J., \& Powell, W. W. (1983). The iron cage revisited: Institutional isomorphism and collective rationality in organizational fields. American 
Sociological Review, 147-160.

Drasin, W. J. (2012). New York's law allowing trafficked persons to bring motions to vacate prostitution convictions: Bridging the gap or just covering it up. Touro Law Review, 28, 489.

FBI (2013). Uniform crime report clearance rates: 2012. Retrieved from http://www.fbi.gov/about-us/cjis/ ucr/crime-in-the-u.s/2012/crime-in-the-u.s.-2012/ offenses-known-to-law-enforcement/clearances

$\mathrm{FBI}$ (n.d.). UCR program adds human trafficking offenses to data collection: Includes more specific prostitution offenses. Retrieved from http:// www.fbi.gov/about-us/cjis/cjis-link/may-2013/ucrprogram-adds-human-trafficking-offenses-to-datacollection-includes-more-specific-prostitutionoffenses

Findley, K. A., \& Scott, M. S. (2006). The multiple dimensions of tunnel vision in criminal cases. Wisconsin Law Review, 291.

Geist, D. (2012). Finding safe harbor: Protection, prosecution, and state strategies to address prostituted minors. Legislation \& Policy Brief, 4, p. 67.

Gigerenzer, G., \& Todd, P. M. (1999). Simple Heuristics that Make Us Smart. New York, NY: Oxford University Press.

Green, S. T. (2008). Protection for victims of child sex trafficking in the United States: Forging the gap between U.S. immigration laws and human trafficking laws. UC Davis Journal of Juvenile Law \& Policy, 12, 309.

Hopper, E., \& Hidalgo, J. (2006). Invisible chains: Psychological coercion of human trafficking victims. Intercultural Human Rights Law Review, 1, 185-209.

Kittling, N. (2006). God bless the child: The United States' response to domestic juvenile prostitution. Nevada Law Journal, 6, 913.

Koper, C. S., Guterbock, T. M., Woods, D. J., Taylor, B., \& Carter, T. J. (2013). Overview of: "The effects of local immigration enforcement on crime and disorder: A case study of Prince William County, Virginia." Criminology \& Public Policy, 12(2), 237-238.

National Center for Missing and Exploited Children (NCMEC). (n.d.). Commercial sexual exploitation of children: A fact sheet. Retrieved from http://www. missingkids.com/en_US/documents/CCSE_Fact_She et.pdf

Office of Juvenile Justice and Delinquency Prevention (OJJDP). (2013). National slavery and human trafficking prevention month observed in January. Retrieved from http://www.ojjdp.gov/newsletter/ 240749/topstory.html

Office of Juvenile Justice and Delinquency Prevention (OJJDP). (2014). Commercial sexual exploitation of children field-initiated research and evaluation program. Retrieved from http://www.ojjdp.gov/ grants/solicitations/FY2014/CSECFIRE.pdf

Office of Victims of Crime Training and Technical
Assistance Center (OVCTTAC). (n.d.). The arrest, detain, and hold dilemma. Retrieved from https://www.ovcttac.gov/TaskForceGuide/EGuide/ WebHelp/12f_6.6c_The_Arrest,_detain,_and_hold_ dilemma.htm

Polaris Project. (2013). Safe harbor-protecting sexually exploited minors (p. 4). Retrieved from http:// www.polarisproject.org/storage/2013-AnalysisCategory-6-Safe-Harbor.pdf

Puzzanchera, C., \& Kang, W. (2013). Easy access to FBI arrest statistics 1994-2010. Retrieved from http://www.ojjdp.gov/ojstatbb/ezaucr

Reid, J. (2010). Doors wide shut: Barriers to the successful delivery of victim services for domestically trafficked minors in a southern U.S. metropolitan area. Women \& Criminal Justice, 20(1-2), 147-166.

Reid, J., \& Jones, S. (2011). Exploited vulnerability: Legal and psychological perspectives on child sex trafficking victims. Victims \& offenders: An International Journal of Evidence-Based Research, Policy, and Practice, 6(2), 207-231.

Scarborough, M. (2008). Safe harbour for exploited children act, TITLE 8-A. Retrieved from http:// assembly.state.ny.us/leg/?default_fld=\%0D\%0A\&b $n=A 05258$ \&term $=2007 \&$ Summary $=Y \& A c t i o n s=Y \& V$ otes $=Y \&$ Text $=Y$

Schwartz, S. (2008). Harboring concerns: The problematic conceptual reorientation of juvenile prostitution adjudication in New York. Columbia Journal of Gender and Law, 18, 235. Shared Hope International Retrieved from http:// sharedhope.org/wp-content/uploads/2012/09/SHI_ National_Report_on_DMST_2009without_cover.pdf

Shared Hope International. (2009). The National Report on Domestic Minor Sex Trafficking: America's Prostituted Children. Retrieved from http:// sharedhope.org/wp-content/uploads/2012/09/SHI_ National_Report_on_DMST_2009without_cover.pdf

Stevens, V. (2010) Act relating to sex crimes involving minors, Pub. L. No. 6476. Retrieved from http:// apps.leg.wa.gov/documents/billdocs/2009-10/Pdf/ Bills/Senate\%20Passed\%20Legislature/6476-S.PL.pdf

Supreme Court of Texas. (2010). In the Matter of B.W., (No. 08-1044). Retrieved from http://www. supreme.courts.state.tx.us/historical/2010/jun/081 044.pdf

United Nations. (2000). Protocol to Prevent, Suppress and Punish Trafficking in Persons, Especially Women and Children, Supplementing the United Nations Convention Against Transnational Organized Crime. Vienna: UNODC. Retrieved from http://www. uncjin.org/Documents/Conventions/dcatoc/final_d ocuments_2/convention_\%20traff_eng.pdf

U.S. v. Curtis (2006). No. 06-3047. Government's Memorandum in Aid of Sentencing.

U.S. Department of Justice. (2013). Attorney general's 
annual report to congress and assessment of U.S. government activities to combat trafficking in persons: Fiscal year 2011. Washington, D.C.: U.S. Department of Justice. Retrieved from http:// www.justice.gov/ag/annualreports/agreporthuman trafficking2011.pdf

U.S. Department of State. (n.d.). U.S. laws on trafficking in persons. Retrieved from http://www.state.gov/ $\mathrm{j} /$ tip/laws

Van der Laan, P.H., Smit, M., Busschers, I., \& Aarten, P. (2011). Cross-border trafficking in human beings: Prevention and intervention strategies for reducing sexual exploitation. Campbell Systematic Reviews, 9.

Victims of Trafficking and Violence Protection Act of 2000. (2000). United States of America. Public Law 106-386 [H.R. 3244]. 28 October 2000.
Wharton, R. (2010). A new paradigm for human trafficking: Shifting the focus from prostitution to exploitation in the trafficking victims protection act. William \& Mary Journal of Women and the Law, 16(3), 753-780.

Wooditch, A. (2011a). The efficacy of the trafficking in persons report: A review of the evidence. Criminal Justice Policy Review, 22(4), 471.

Wooditch, A. (2011b). Human trafficking law and social structures. International Journal of Offender Therapy and Comparative Criminology, 56(5), 673.

Wooditch, A. C., DuPont-Morales, M. A., \& Hummer, D. (2009). Traffic jam: A policy review of the United States' Trafficking Victims Protection Act of 2000. Trends in Organized Crime, 12(3-4), 235-250.

\section{About the Author}

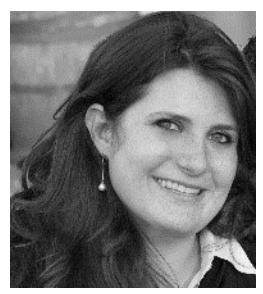

\section{Dr. Kimberly Mehlman-Orozco}

Kimberly Mehlman-Orozco, Ph.D. most recently served as Executive Director of The Justitia Institute (TII), a research non-profit focused on issues related to human trafficking, immigration, and social justice. Dr. Mehlman-Orozco earned her degree from the Department of Criminology, Law and Society at George Mason University. She has been involved with the anti-trafficking discourse in a number of capacities, including serving as a steering committee member on several anti-trafficking task forces and collaborating with federal and state law enforcement to improve anti-trafficking practices. 